\title{
Middle School Student Statistical Literacy Based on Adversity Quotient
}

\author{
Vicky Firdausi Nuzula ${ }^{1}$ Ismail $^{2}$ \\ ${ }^{1,2}$ Program Studi Pendidikan Matematika, Fakultas Matematika dan Ilmu Pengetahuan Alam Universitas Negeri Surabaya, \\ Jl. Ketintang, Gayungan, Surabaya, Jawa Timur, 60231 \\ vicky.17030174044@mhs.unesa.ac.id
}

\begin{abstract}
Statistical literacy was needed to read, interpret, conclude, and communicate data. One of the external factors was Adversity Quotient (AQ) in determining attitudes when faced difficulties related to statistical literacy. This type of research was descriptive research with a qualitative approach, with the aim was describing the statistical literacy of middle school students in terms of Adversity Quotient. Subjects consisted of 3 students who were selected from 31 students based on the results of the Adversity Response Profile with categories 1 subject of climber type, 1 subject of camper type, and 1 subject of quitter type, who were given statistical literacy tests and interviews. The results showed that: climber, camper, and quitter type subjects have not been able to present data in the appropriate diagrams and make criticisms of the data. Climber type subject was able to give reasons with mathematical calculations and apply appropriate statistical concepts, so that categorized in the critical level; Camper type subject was able to identify statistical terminology, but have not applied it, so that categorized in the inconsistent level; Quitter type subject only used imagination and provided non-statistical reasons, so that categorized in the informal level.
\end{abstract}

Keywords: Statistical literacy, Adversity Quotient

\begin{abstract}
Abstrak
Literasi statistik dibutuhkan dalam membaca, menginterpretasi, menyimpulkan serta mengomunikasikan data. Salah satu faktor yang mempengaruhi literasi statistik yaitu Adversity Quotient (AQ) dalam penentuan sikap ketika dihadapkan kesulitan terkait soal literasi statistik. Jenis penelitian ini yaitu penelitian deskriptif dengan pendekatan kualitatif, dengan tujuan mendeskripsikan literasi statistik siswa SMP ditinjau dari Adversity Quotient. Subjek terdiri dari 3 siswa yang diambil berdasarkan hasil Adversity Response Profile dengan kategori 1 subjek tipe climber, camper, dan quitter. Kemudian subjek diberi tes soal literasi statistik dan wawancara. Hasil penelitian menunjukkan bahwa: subjek tipe climber, camper, dan quitter belum mampu menyajikan data dalam bentuk diagram yang sesuai dan membuat kritik dari data. Subjek tipe climber mampu memberikan alasan dengan perhitungan matematis dan menerapkan konsep statistika yang sesuai, sehingga berada di level critical; Subjek tipe camper mampu mengidentifikasi terminologi statistika, namun belum menerapkannya, sehingga berada di level inconsistent; subjek tipe quitter hanya menggunakan imajinasi dan memberikan alasan non-statistik, sehingga berada di level informal.

Kata kunci: Literasi statistik, Adversity Quotient
\end{abstract}

Copyright (c) 2021 Vicky Firdausi Nuzula, Ismail

$\triangle$ Corresponding author: Vicky Firdausi Nuzula

Email Address: vicky.17030174044@mhs.unesa.ac.id (Jl. Ketintang, Gayungan, Surabaya, Jawa Timur, 60231)

Received 19 June 2021, Accepted 15 July 2021, Published 21 July 2021

\section{INTRODUCTION}

In the 21st century, statistical literacy was needed to read, interpret, conclude, and communicate data. According to (Gal \& Weldon, 2002)statistical literacy was described as the ability to interpret, evaluate critically, and communicate information presented in the data. This understanding means that not only the ability to read, analyze, interpret data, but also students are required to be able to communicate data. This was also expressed by (Hariyanti, 2019; Yolcu, 2014) that communicating data was one aspect of statistical literacy that must be achieved by students. So, it can be concluded that statistical literacy is the ability to read, interpret, conclude, and communicate data.

According to (Aoyama \& Stephens, 2003) the meaning of reading includes: basic reading of the table or graph presented, understanding keywords or things that stand out from a graph, and connecting the 
information presented in the two graphs. The meaning of interpret according to (Hafiyusholeh et al., 2017) includes: being able to make appropriate graphs, determine the value of measure of tendency; concluding data means making inferences from data; (Gould, 2017) argues that communicating data means being able to make evaluations or criticisms and make predictions about the data presented. Based on (Khadijah et al., 2018; Setiawan, 2020) the aspect of presenting data in the tables and diagrams was the most developed subject at all levels, in middle school, students are taught to understand data from a table, how to present data in diagrams, determine the measure of tendency, and make predictions. Therefore, statistical literacy is needed in the middle school level, so that students are able to read, interpret, conclude, and communicate data.

(Watson \& Callingham, 2003)classified statistical literacy levels into 6: idiosyncratic, informal, inconsistent, consistent non-critical, critical, and critical mathematical. There were several studies that have tested the statistical literacy of middle school students such as (Hariyanti, 2019; Maryati \& Priatna, 2018; Wildani et al., 2019; Yolcu, 2014), the study said that middle school students were rarely able to make predictions and evaluations from data, when made conclusions from data, middle school students rarely use mathematical calculations or involve statistical terminology and apply them. Therefore, skills in statistical literacy are very important for middle school students (Priyambodo \& Maryati, 2019)

According to (Gal \& Weldon, 2002), it was difficult to describe statistical literacy if it did not show 5 basic knowledge, such as: literacy skills, statistical knowledge, mathematical knowledge, context knowledge, and critical questions. In addition, there were several external factors that affect statistical literacy such as belief, attitude, and critical attitudes, and so on. (Carmichael \& Hay, 2010) argued that a relationship can be made between statistical literacy and Adversity Quotient (AQ), because there are several things that can affect Adversity Quotient (AQ), such as belief and attitude (Stoltz, 2003), the external factors of statistical literacy.

Adversity Quotient (AQ) according to (Stoltz, 2003) is the ability to survive in difficulties. Adversity Quotient (AQ) can help students strengthen their ability and persistence in dealing with problems. (Muhtarom, 2019)argued that Adversity Quotient (AQ) is a measurement of a person's ability to see, face, and solve difficulties. (Hastuti et al., 2017) said that Adversity Quotient (AQ) is a person's ability to survive in difficulties and effort in solving difficulties. From these opinions, it can be concluded that Adversity Quotient (AQ) is the ability to survive in seeing, facing, and solving difficulties.

(Stoltz, 2003) classified Adversity Quotient (AQ) into 3 types: climbers, who have a strong belief and understanding that something urgent must be resolved immediately, so that everything can be done. Camper is a group of people who have tried to overcome the difficulties experienced but have not reached the peak of completion. When faced with difficulties, they consider the risks involved and the rewards. Quitter, who stop when facing difficulties before trying, show less ambition, minimal enthusiasm, substandard quality, and take as few risks as possible and not creative. This is also in line with (Hastuti et al., 2017; MZ et al., 2017; Purnamasari et al., 2018) which examined Adversity Quotient in middle school students. 
(Stoltz, 2003) argued that there were four basic dimensions that result in a high Adversity Quotient (AQ) ability, such as: control, origin and ownership, reach, and endure (CO2RE). The assumption of difficulties that occur in students can be seen from how they survive in seeing, facing, and solving difficulties when given statistical literacy questions. However, Gal in (Watson, 2004) argued that attitude and belief are very motivating students in critical thinking which external factors of statistical literacy. In this case, critical thinking will determine the control of a person in transferring information on the data presented into an interpretation of a diagram and providing an evaluation of the data presented. Origin or Ownership in the Adversity Quotient (AQ) aspect relates to how a person feels guilty so that learns to be better (Stoltz, 2003), which in statistical literacy this aspect is closely related to how students evaluate a data or it can be said students' ability to communicate data (Chick \& Pierce, 2013; Sharma, 2017).

Therefore, this study discusses the literacy of middle school students based on Adversity Quotient, so that research questions arise, such as: How is statistical literacy of middle school students based on Adversity Quotient (AQ) of climber type?; How is the statistical literacy of middle school students based on Adversity Quotient (AQ) of camper type?; How is the statistical literacy of middle school students based on Adversity Quotient (AQ) of quitter type?. The objectives of this study are to describe the statistical literacy of middle school students based on Adversity Quotient (AQ) of climber type, to describe the statistical literacy of middle school students based on Adversity Quotient (AQ) of camper type, and to describe the statistical literacy of middle school students based on Adversity Quotient (AQ) of quitter type.

\section{METHOD}

This research was a descriptive research with a qualitative approach. The subjects used were 3 students selected from 31 middle school students in IX grade with purposive random sampling technique. Subjects were selected based on the results of the Adversity Response Profile (ARP) test from 31 students, then from the results of the ARP test were taken 3 subjects with categories: climber, camper, quitter type, every category was taken 1 subject, who given a written test based on statistical literacy; and interviews. There are 2 instruments that used in this study, the main instrument, and the supporting instrument. The main instrument was the researcher. The supporting instruments were: (1) Adversity Response Profile (ARP) questionnaire consist a questionnaire that was created by Stoltz, containing 20 questions related to the 4 basic dimensions of Adversity Quotient (AQ). (2) Statistical Literacy Test (TSLS) was a question used to obtain written data to describe students' statistical literacy. TSLS is in the form of essay question which modification of (Hafiyusholeh et al., 2017) and (Watson \& Callingham, 2003) with reference to the 6 level of statistical literacy by (Gal \& Weldon, 2002). The questions and interview protocol were consulted and validated by expert validators. The technique of analyzing data from the Adversity Response Profile (ARP) by categorizing the type of Adversity Quotient (AQ) based on the following table: 
Table 1. Adversity Quotient Category

\begin{tabular}{|c|c|c|}
\hline No & Adversity Response Profile (ARP) Score & Adversity Quotient (AQ) Category \\
\hline 1. & $166-200$ & Climber \\
\hline 2. & $95-134$ & Camper \\
\hline 3. & $0-59$ & Quitter \\
\hline
\end{tabular}

The written test data analysis was based on the following statistical literacy indicators that modified from (Sharma, 2017):

Table 2. Statistical Literacy Indicator

\begin{tabular}{|l|l|l|l|l|}
\hline No. & Statistical Literacy Aspect & Code & \multicolumn{1}{|c|}{ Indicator } & Code \\
\hline 1. & Reading Data & L1 & $\begin{array}{l}\text { Student is able to identify what is known } \\
\text { and asked in the questions }\end{array}$ & L1.1 \\
\cline { 3 - 5 } & & & $\begin{array}{l}\text { Student is able to identify the statistical } \\
\text { terminology used in the questions }\end{array}$ & L1.2 \\
\hline 2. & Interpreting Data & L2 & $\begin{array}{l}\text { Student is able to present data in } \\
\text { appropriate form, for example: tables, } \\
\text { point charts, line charts, bar charts, or } \\
\text { pie charts }\end{array}$ & L2.1 \\
\cline { 4 - 6 } & & $\begin{array}{l}\text { Student is able to connect data with } \\
\text { phenomena that occur around them }\end{array}$ & L2.2 \\
\cline { 4 - 6 } & Concluding Data & $\begin{array}{l}\text { Student is able to apply the concept of } \\
\text { measure of tendency properly }\end{array}$ & L2.3 \\
\hline 3. & L3 & $\begin{array}{l}\text { Student is able to make conclusions } \\
\text { based on the data or diagrams that have } \\
\text { been presented }\end{array}$ & L3.1 \\
\hline 4. & Communicating Data & L4 & $\begin{array}{l}\text { Student is able to make prediction from } \\
\text { the data }\end{array}$ & L4.1 \\
\cline { 3 - 5 } & & $\begin{array}{l}\text { Student is able to make evaluation or } \\
\text { critic from the data }\end{array}$ & L4.2 \\
\hline
\end{tabular}

After the written data were analyzed using the indicators in Table 2, then each subject was classified based on the level of statistical literacy (Watson \& Callingham, 2003)in the following table:

Table 3. Statistical Literacy Level

\begin{tabular}{|c|c|l|}
\hline Level & Statistical Literacy Level & \multicolumn{1}{c|}{ Characteristics } \\
\hline 1 & idiosyncratic & $\begin{array}{l}\text { When reading, interpreting, summarizing, and } \\
\text { communicating data, student answers based on } \\
\text { experience. }\end{array}$ \\
\hline \multirow{3}{*}{$\begin{array}{l}\text { informal } \\
3\end{array}$} & $\begin{array}{l}\text { When reading, interpreting, concluding, and } \\
\text { communicating data, student only interact with } \\
\text { statistical terminology, when making conclusions } \\
\text { students tend to imagine and use inappropriate } \\
\text { explanations, such as non-statistical or intuitive } \\
\text { explanations. }\end{array}$ \\
\hline & $\begin{array}{l}\text { When reading, interpreting, concluding, and } \\
\text { communicating data, student begins to try to find } \\
\text { the relationship between the data presented and } \\
\text { the phenomenon that occurs, but it is not suitable } \\
\text { for providing qualitative reasons. }\end{array}$ \\
\hline
\end{tabular}




\begin{tabular}{|c|c|l|}
\hline 4 & Consistent non-critical & $\begin{array}{l}\text { Student is able to find the relationship between } \\
\text { the data presented and the phenomena that occur } \\
\text { by using statistical terminology such as using the } \\
\text { average, mean, or mode but inappropriate. }\end{array}$ \\
\hline 5 & Critical & $\begin{array}{l}\text { Student is able to apply statistical terminology } \\
\text { such as mean, median, and mode appropriately. }\end{array}$ \\
\hline 6 & Critical Mathematical & $\begin{array}{l}\text { Students is able to make accurate evaluations and } \\
\text { predictions using statistical terminology based on } \\
\text { the data. }\end{array}$ \\
\hline
\end{tabular}

The analysis of interview results included: data reduction, data presentation, making conclusions (Sugiyono, 2019).

\section{RESULT AND DISCUSSION}

\section{The Analysis of Adversity Response Profile (ARP)}

The following table shows the selected subjects based on the results of the Adversity Response Profile (ARP):

Table 4 The Result of Adversity Response Profile

\begin{tabular}{|c|c|c|c|c|}
\hline No & Subject & ARP Score & AQ Category & Code \\
\hline 1. & ARW & 173 & Climber & S-Cl \\
\hline 2. & YWM & 116 & Camper & S-Ch \\
\hline 3. & GPH & 59 & Quitter & S-Qu \\
\hline
\end{tabular}

Analysis and Discussion of Middle School Students Statistical Literacy on The Subject of Climber AQ Type $(\mathrm{S}-\mathrm{Cl})$

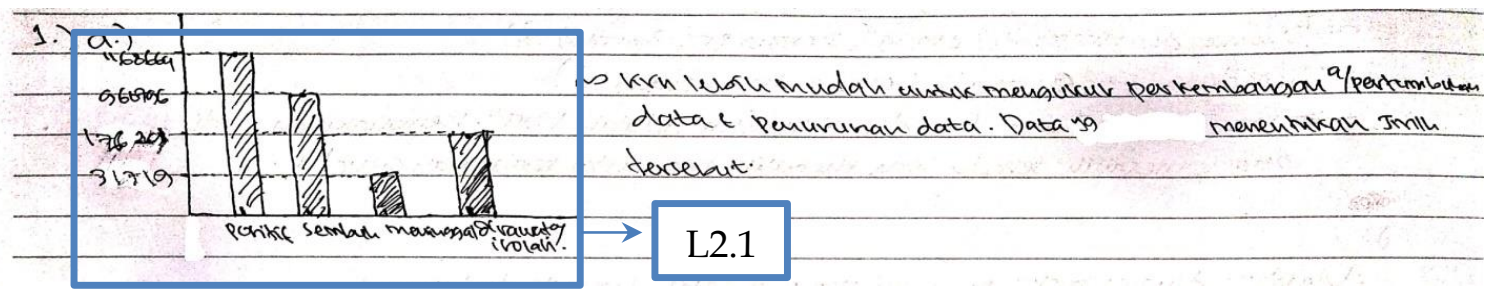

Picture 1. The Solution of S-Cl of Question 1a

In this solution, $\mathrm{S}-\mathrm{Cl}$ converts the information presented into a bar chart by adding the positive numbers for Covid-19, recover, death, and treatment/isolation with additional numbers from each data. When presenting data on Covid-19 patients who were treated/isolated based on the results of interviews, S$\mathrm{Cl}$ was confused in presenting the data, because the information presented did not state how much the decline was. The consideration used by $\mathrm{S}-\mathrm{Cl}$ in presenting data in the form of a bar chart because easier to understand. Thus, it can be concluded that $\mathrm{S}-\mathrm{Cl}$ has not succeeded in presenting data into the appropriate diagram, namely a pie chart. This was in line with (Maryati \& Priatna, 2018; Wildani et al., 2019) which 
states that in middle school level there were many students who had difficulty converting the information presented into the appropriate diagrams. It shows that $\mathrm{S}-\mathrm{Cl}$ was able to read data (L1.1), the strategy used by $\mathrm{S}-\mathrm{Cl}$ to conclude (L3.1) by identifying the known information, not using intuition or imagination. In addition, $\mathrm{S}-\mathrm{Cl}$ was able to relate the information presented with the phenomena that occur around it, according to the following interview below:

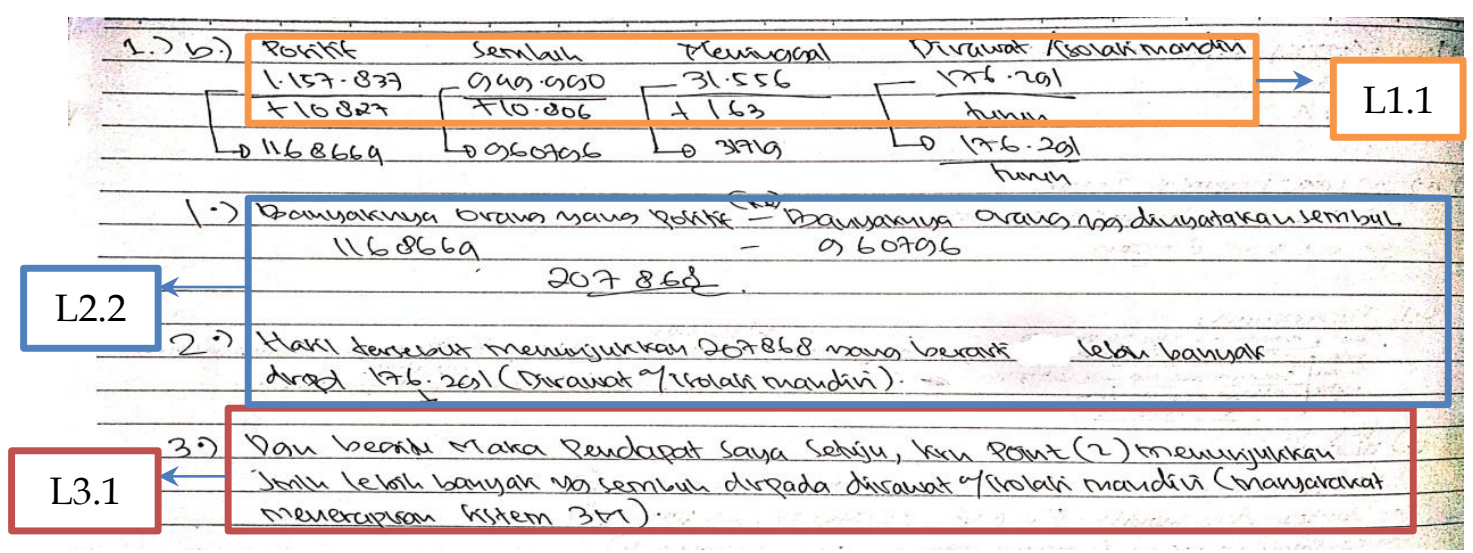

Picture 2. The S-Cl Solution of Question $1 \mathrm{~b}$

Researcher: "Is there a relationship between the data presented, the answers you gave, and the phenomena that occur around you and do they match or not with the data presented?"

S-Cl: "Yes, there are many people around me who have implemented 3M, although some have violated it, but there are people who obey and apply $3 M$ also. However, the data said that the number of positive covid-19 were up, maybe because the immune from themselves or social distancing, etc." (L2.2),

The interview above shows that $\mathrm{S}-\mathrm{Cl}$ was able to relate the data presented to the phenomena that occur around it (L2.2) and evaluate whether the data relate to the phenomenon or not (L4.2). This was in line with (Priyambodo \& Maryati, 2019) who said that the average student who has a critical attitude was able to relate the information received to the phenomena of life. $\mathrm{S}-\mathrm{Cl}$ had the characteristics expressed by (Muhtarom, 2019); (Stoltz, 2003) that someone who has a climber type must have a critical attitude in order to successfully pass the challenges.

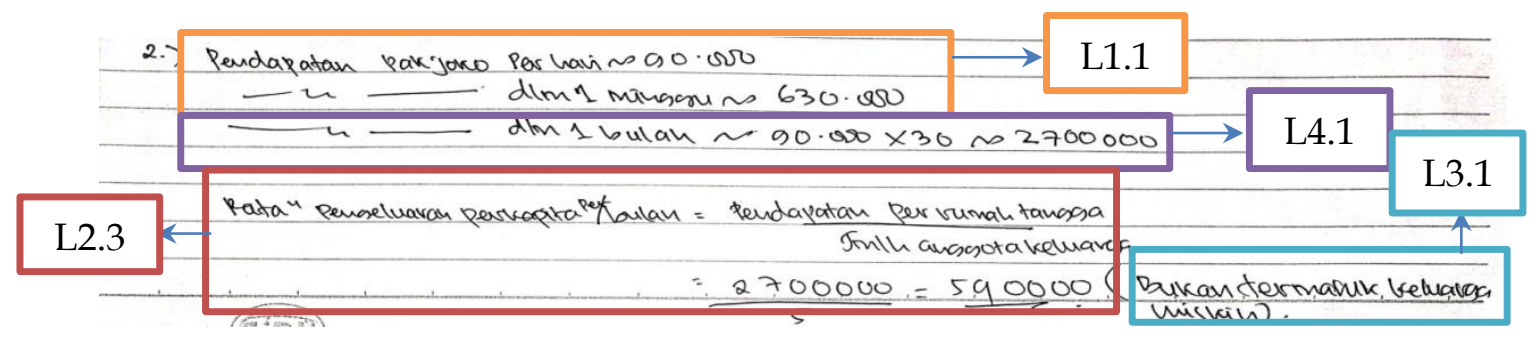

Picture 3. The S-Cl Solution of Question 2

The answers above show that S-Cl was capable of L1.1, L2.3, L3.1, and L4.1. In answering the questions given, $\mathrm{S}-\mathrm{Cl}$ had understood what is known and asked in the questions, besides that $\mathrm{S}-\mathrm{Cl}$ also knows what information is useful for answering questions (L1.1). S-Cl was able to predict how much Pak 
Joko's income in 1 month (L4.1) with mathematical calculations. S-Cl was also able to identify the statistical terminology used in problem L1.2. This was expressed in the following interview:

Researcher: "Is there any statistical terminology in the questions?"

$S$-Cl: "Yes, there is, average. The average referred to the average per capita income per month that had already been defined." (L1.2, L2.3)

From the interview above, it can be concluded that $\mathrm{S}-\mathrm{Cl}$ was able to identify statistical terminology contained in the questions (L1.2). This ability in line with (Hariyanti, 2019). In addition, S-Cl was also able to apply the concept of measure of tendency to answer the questions. In providing conclusions, S-Cl compared Pak Joko's income and the poverty line of Mojokerto Regency. This can be seen from the following interview below:

Researcher: "How did you make a conclusion that Pak Joko was not a poor citizen?"

S-Cl: "After I calculated the average income per capita per month of Pak Joko's family, I compared the results with the poverty line of Mojokerto Regency, because the results were greater then poverty line, so the conclusion: Pak Joko's family was not a poor family, because the story said that if a resident who has an average monthly per capita income below the poverty line is classified as poor, and it turns out that the average monthly per capita income of Mr. Joko's family was above the poverty line of Mojokerto, it can be concluded that Mr. Joko's family was not included poor families in Mojokerto Regency." (L2.3, L3.1)

The interview above shows that in concluding data, $\mathrm{S}-\mathrm{Cl}$ involved the information that known on the question and applying the concept of average in finding the desired answer. This ability was rarely owned by middle school students according to (Hariyanti, 2019). This ability in line with the characteristics of a climber who had creative ideas in achieving a goal (Stoltz, 2003). Therefore, S-Cl's ability to read, interpret, conclude, and communicate data was classified at a critical level, because $\mathrm{S}-\mathrm{Cl}$ was able to identify and apply statistical concepts correctly.

\section{Analysis and Discussion of Middle School Students Statistical Literacy on The Subject of Camper AQ Type (S-Ch)}

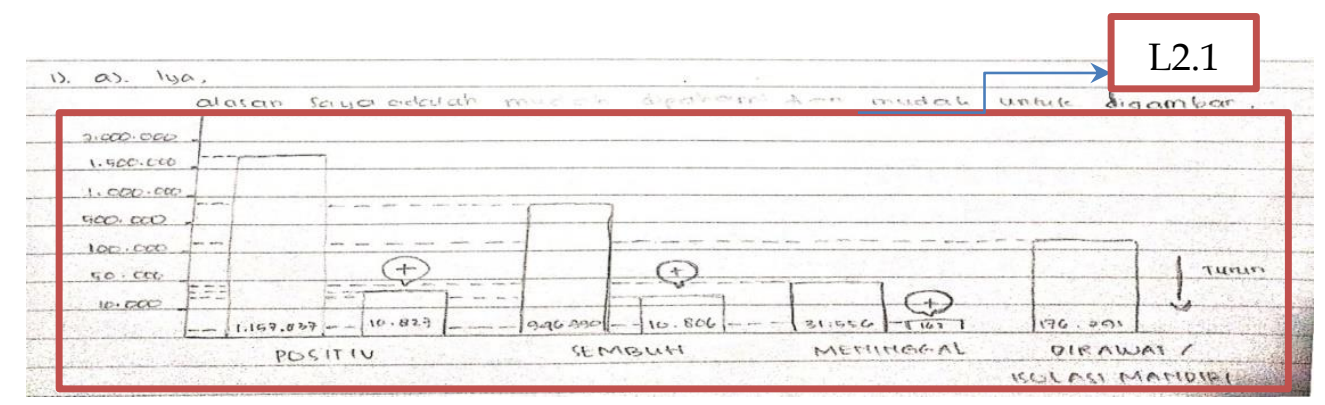

Picture 4. The S-Ch Solution of Question 1a

In code L2.1, S-Ch drawn a bar chart, although it is not appropriate, S-Ch compared positive numbers, recovers, dies, and isolation with the numbers of increasing or decreasing. However, the graph does not sum the numbers before the increasing or decreasing. From this, it can be seen that the combination is not 
used by S-Ch. In this case, S-Ch means had not been able to drawn the appropriate diagram. The reason used by $\mathrm{S}-\mathrm{Ch}$ in making graphs can be seen in the following interview:

Researcher: "Why did you choose a bar chart, was it appropriate?"

$S$-Ch: "The reason, because bar charts were easier to understand and draw. In my opinion, it was suitable because it was easy."

From the interview above, it can be seen that the considerations used by S-Ch in presenting data by diagrams were only used the element of convenience without paying attention to the element of suitability. This was in line with (Amalia, 2020; Khadijah et al., 2018) which says that junior high school students had difficulty in presenting data by an appropriate diagram. In this case, it was appropriate with the characteristics of an AQ camper type, such as taking shortcuts but not suitable for achieving goals and cannot reach that goal (Stoltz, 2003); (Hastuti et al., 2017).

From the answers given, S-Ch in concluding a data only looked at the phenomena and impacts that occurred

b)

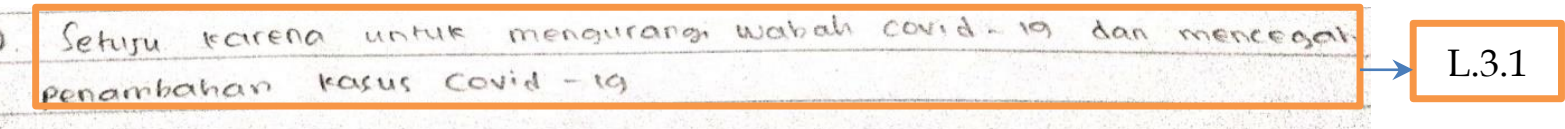

Picture 5. The S-Ch Solution of Question 1b

around life. This was known from the following interview:

Researcher: "From the answers you have given, what were the considerations that made you agree with the statement that many Indonesians had implemented 3M?"

S-Ch: "I saw a phenomenon that happening around me, that most of the people around me had implemented

$3 \mathrm{M}$ even though some did not apply, but most of people applied it. Then, if many people implement

3M, then this will reduce the Covid-19 outbreak and prevent additional Covid-19 cases."

The interview shows that $\mathrm{S}-\mathrm{Ch}$ in concluding a data used a strategy by connecting with the phenomena that occur around it, without involving the data presented or statistical concepts. S-Cl also has not been able to make evaluations (L4.2) related to surrounding phenomena. This was in line with the attitude of a camper who have limited abilities in dealing with a problem (Stoltz, 2003). This opinion is also reinforced (Hariyanti, 2019) that in connecting data with phenomena that occur around middle school students, it is not based on mathematical calculations.

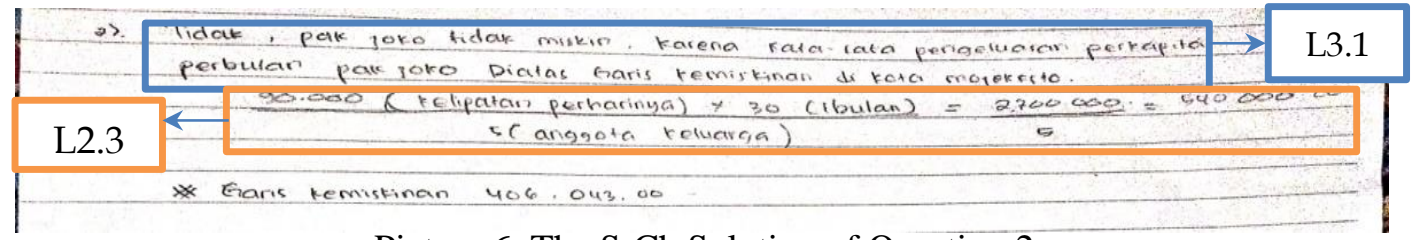

Picture 6. The S-Ch Solution of Question 2

Code (L2.3) shows that S-Ch was able to apply the concept of measure of tendency, average. This indicated that S-Ch was able to interpret a data by applying the concept of measure of tendency, average. Code (L3.1) indicated that S-Ch was able to conclude a data. However, S-Ch has not shown a mathematical calculation of Pak Joko's income in 1 month. This can be said that S-Ch did not use mathematical 
calculations when making predictions from data (L4.1). Then S-Ch made a conclusion that had found. This was in line with (Hariyanti, 2019; Wildani et al., 2019) that middle school students in making prediction were not based on mathematical calculations. Therefore, S-Ch's ability to read, interpret, conclude, and communicate data was classified at an inconsistent level, because S-Ch seldom used mathematical calculation to predict data and did not applied statistical concept to evaluate data, just connected with the phenomena around.

Analysis and Discussion of Middle School Students Statistical Literacy on The Subject of Quitter AQ Type $(S-Q u)$

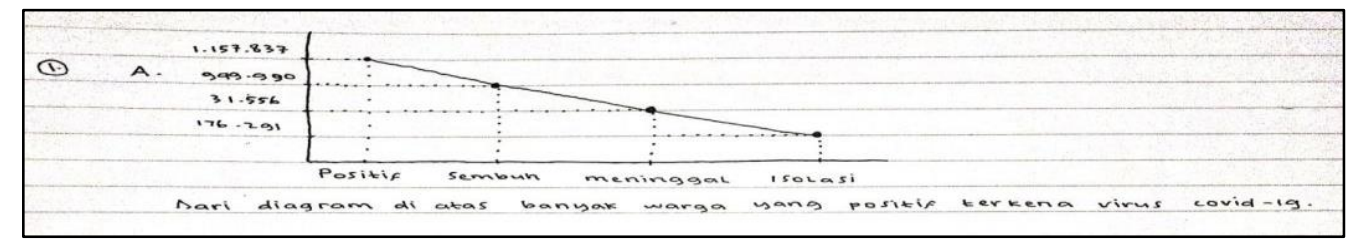

Picture 7. The S-Qu Solution of Question 1a

$\mathrm{S}-\mathrm{Qu}$ presented the data in a line chart. From these answers, it can be seen that S-Qu had not been able to interpret data in an appropriate diagram, a pie chart. S-Qu paid less attention that each point on the line chart will have a value. The analysis in line with the character of a quitter, namely not understanding the situation in solving a problem (Stoltz, 2003); (Septianingtyas \& Jusra, 2020). The following interview shows that $\mathrm{S}-\mathrm{Qu}$ does not know what type of diagram was being drawn.

Researcher: "What diagrams did you use to present the data?"

S-Qu: "Emmm... Dot chart."

The interview above shows misconception between what was presented, and the type of diagram mentioned at the time of the interview. Then the strategy used by S-Qu in making the diagram can be seen from the following interview:

Researcher: "What strategy did you use in presenting the data in the diagram you drew?"

$S$-Qu: "First I saw that there were positive numbers, recovered, died, and isolation, after that I tried to put them in a diagram by making dots according to the values stated in the information presented. Then I connect the dots with a line."

Researcher: "So the type of diagram you present was called a dot chart or a line chart?"

S-Qu: "Oh... I means line chart."

The interview above shows that the strategy used by S-Qu in presenting the diagram was how to make a line chart. This was in line with (Stoltz, 2003) which said that a quitter tends to ignore the potential they have. This was shown by the way they do not realize that the diagram presented was a line chart.I

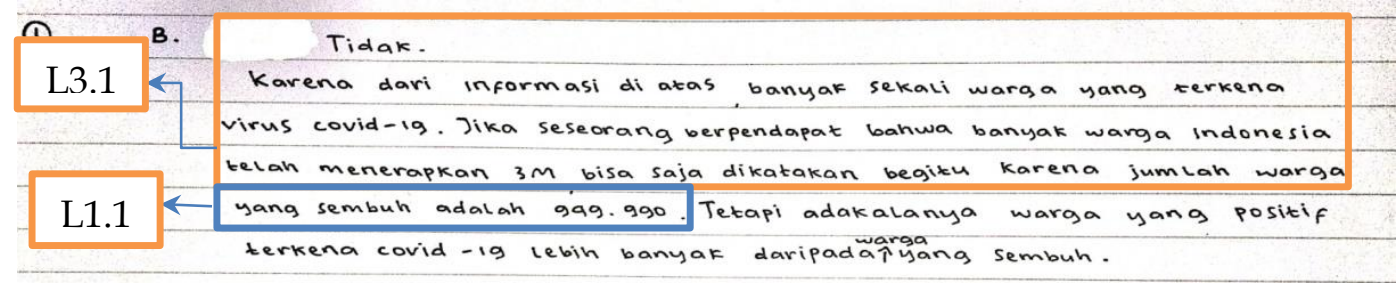

Picture 8. The S-Qu Solution of Question 1b 
Code (L1.1) shows that in concluding data from L3.1, S-Qu only uses one piece of information that relevant to give a conclusion. This was in line with the attitude of a quitter who has little ambition and creativeness in making an idea (MZ et al., 2017). So that S-Qu cannot achieve the desired goal. S-Qu also has not been able to make evaluations (L4.2) related to surrounding phenomena with statistical concept. The strategy used by S-Qu in concluding the data can be seen through the following interview: Researcher: "What strategy did you use to answer or conclude which do not agree with that opinion?" S-Qu: "First of all, I saw the positive number of Covid-19, because it showed the highest number, so I don't agree with the statement in the question" (L3.1)

The interview above shows that in making conclusions, $\mathrm{S}-\mathrm{Qu}$ only looked at one side without paying attention to the death rate and the number of Covid-19 isolation or mathematical calculations. S-Qu only used a few ideas in concluding data (L3.1) and did not evaluate the data whether or not it is relate with the surrounding phenomenon. This was in line with the character of S-Qu which tends to be creativeness to achieve a goal (Stoltz, 2003), and not based on mathematical calculations (Hariyanti, 2019).

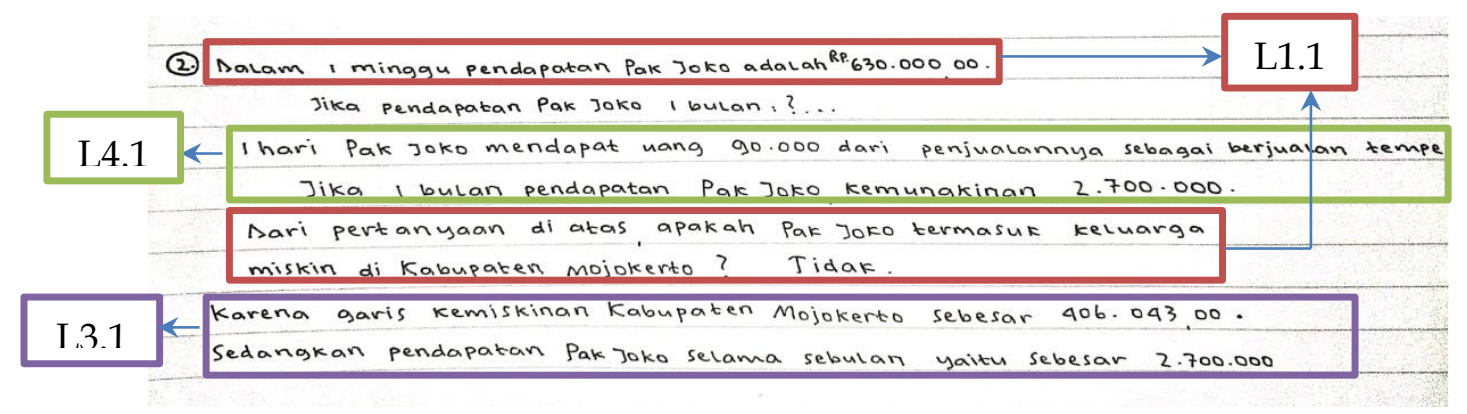

Picture 9. The S-Qu Solution of Question 2

Code (L1.1) shows that S-Qu was able to identify what known and asked about in the question, but there was one relevant information that not used by S-Qu, which was about the number of Pak Joko's family members. Code L4.1 shows that S-Qu was able to predict the data but does not use mathematical calculations. There were several steps and measure of tendency that S-Qu did not involve in making conclusions. This can be seen from the following interview:

Researcher: "In finding the average monthly income per capita, did you involve the number of Pak Joko's family members?"

S-Qu: "No, I did not"

Researcher: "Means that there were no statistical concepts that you use to make that conclusion?"

S-Qu: "Actually there was an average concept in that question, but I'm confused about where to apply it, so I immediately looked for Pak Joko's income for one month and then I compared it to the Mojokerto Regency poverty line." (L1.2)

The interview above shows that S-Qu had not been able to apply the concept of measure of tendency, average. However, S-Qu was able to identify statistical terminology (L2.1) contained in the questions. This was in line with the character of a quitter who does not use it potential in achieving a goal (Stoltz, 2003);(Septianingtyas \& Jusra, 2020), and used non-statistics concept when making a prediction (Hariyanti, 
2019). Therefore, S-Qu's ability to read, interpret, conclude, and communicate data was classified at an informal level, because $\mathrm{S}-\mathrm{Qu}$ used mathematical calculation to predict data and non-statistics reason when evaluate or conclude the data.

\section{CONCLUSION}

Based on the analysis and discussion, it can be concluded that the statistical literacy of junior high school students is based on the Adversity Quotient (AQ) as follows:

- Middle school students with climber AQ type had not been able to interpret the data by presenting the data in appropriate diagrams and communicating the data by giving criticism. However, in reading, interpreting, concluding, communicating data, be able able to identify statistical concepts and apply them, so it can be said that was at the level of statistical literacy, which is critical level.

- Middle school students with camper AQ type had not been able to interpret the data by presenting the data in appropriate diagrams and communicating the data by providing evaluations and criticisms. However, in reading, interpreting, concluding, communicating data, they are able to identify the statistical terminology used in the problem but did not apply it, so it can be said that it was at the statistical literacy level, which is inconsistent level.

- Middle school students with quitter AQ type had not been able to interpret the data by presenting the data in appropriate diagrams and communicating the data by providing evaluations and criticisms. In reading, interpreting, concluding, communicating data, they tend to use non-statistical reasons so that it can be said that it was at the level of statistical literacy, which is informal.

\section{Suggestion}

Based on the results of the study, the researchers gave the following suggestions:

- Based on the results of the study, students with climber, camper, and quitter AQ type have not been able to present data in appropriate diagrams. In this case the teacher can provide related explanations about the characteristics of the suitability of presenting data in graphical form, by providing various examples of contexts for presenting data in different diagrams.

- For the next research, it better not only analyze the Adversity Quotient (AQ) climber, camper, and quitter type, but also include an analysis on the transitional type, such as transitional camper and transitional climber with the aim of knowing whether there is a difference in statistical literacy with the 3 AQ types, because from the results of the Adversity Response Profile, it was found that many students were in the transitional AQ category.

\section{REFERENCES}

Amalia, R. (2020). Analisis Kesalahan Siswa SMP Kelas IX di Cimahi Pada Pokok Bahasan Statistika. Jurnal Equation, 3(1), 57-64. https://ejournal.iainbengkulu.ac.id/index.php/equation/article/view/2644

Aoyama, K., \& Stephens, M. (2003). Graph interpretation aspects of statistical literacy: A Japanese 
perspective. Mathematics Education Research Journal, 15(3), 207-225. https://doi.org/10.1007/BF03217380

Carmichael, C., \& Hay, I. (2010). Statistical literacy in the middle school : The relationship between interest , self-efficacy and prior mathematics achievement 1. Journal of Educational and Developmental Psychology, 10, 83-93. www.newcastle.edu.au/journal/ajedp/

Chick, H., \& Pierce, R. (2013). The Statistical Literacy Needed to Interpret School Assessment Data. Mathematics Teacher Education \& Development, 15(2), 1-19. http://search.ebscohost.com/login.aspx?direct=true \&db=eric\&AN=EJ1018712\&site=ehostlive\%5Cnhttp://search.ebscohost.com/login.aspx?direct=true \&db=ehh\&AN=94988608\&site=ehostlive

Gal, I., \& Weldon, K. L. (2002). [Adults' Statistical Literacy: Meanings, Components, Responsibilities]: Discussion. International Statistical Review / Revue Internationale de Statistique, 70(1), 43. https://doi.org/10.2307/1403719

Gould, R. (2017). Data literacy is statistical literacy. Statistics Education Research Journal, 16(1), 22-25. https://iase-web.org/Publication.php?p=SERJ

Hafiyusholeh, M., Budayasa, K., \& Siswono, T. Y. E. (2017). Literasi Statistik: Siswa SMA dalam Membaca, Menafsirkan, dan Menyimpulkan Data. Prosiding SI MaNIs (Seminar Nasional Integrasi Matematika Dan Nilai Islami), 1(1), 79-85.

Hariyanti, F. (2019). Statistical Literacy Siswa SMP dalam Pembelajaran Matematika Student's Statistical Literacy of Junior high school in Learning Mathematics. EKSPOSE: Jurnal Penelitian Hukum Dan Pendidikan, 18(2), 911-920. https://doi.org/http://dx.doi.org/10.30863/ekspose.v18i2.564

Hastuti, T. D., Sari, D. R., \& Riyadi. (2017). Student profile with high adversity quotient in math learning. International Conference on Mathematics, Science, and Education. https://doi.org/10.1088/17426596/983/1/012131

Khadijah, I. N. A., Maya, R., \& Setiawan, W. (2018). Analisis Kemampuan Komunikasi Matematis Siswa Smp Pada Materi Statistika. JPMI Jurnal Pembelajaran Matematika Inovatif, 1(6), 1095-1104. https://doi.org/http://dx.doi.org/10.22460/jpmi.v1i6.p1095-1104

Maryati, I., \& Priatna, N. (2018). Analisis Kemampuan Literasi Statistis Siswa Madrasah Tsanawiyah dalam Materi Statistika. Journal of Medives: Journal of Mathematics Education IKIP Veteran Semarang, 2(2), 205. https://doi.org/10.31331/medives.v2i2.640

Muhtarom. (2019). Profil Keyakinan Pendagogical Content Knowledge Mahasiswa Calon Guru Matematika Ditinjau dari Adversity Quotient. Surabaya: Unesa (Disertasi Tidak Dipublikasikan).

MZ, Z. A., Risnawati, R., Kurniati, A., \& Prahmana, R. C. I. (2017). Adversity Quotient in Mathematics Learning (Quantitative Study on Students Boarding School in Pekanbaru). International Journal on Emerging Mathematics Education, 1(2), 169. https://doi.org/10.12928/ijeme.v1i2.5780

Priyambodo, S., \& Maryati, I. (2019). Peningkatan Kemampuan Literasi Statistis melalui Model Pembelajaran Berbasis Proyek yang Dimodifikasi. Mosharafa: Jurnal Pendidikan Matematika, 8(2), 
273-284. https://doi.org/10.31980/mosharafa.v8i2.496

Purnamasari, F. E., Sujadi, I., \& Slamet, I. (2018). Effect of adversity quotient of junior high school students on reflective thinking process in mathematical problem solving Effect of adversity quotient of junior high school students on reflective thinking process in mathematical problem solving. International Conference on Mathematics, Science, and Education. https://doi.org/10.1088/1742$6596 / 1321 / 2 / 022128$

Septianingtyas, N., \& Jusra, H. (2020). Kemampuan Pemecahan Masalah Matematis Peserta Didik Berdasarkan Adversity Quotient. Jurnal Cendekia : Jurnal Pendidikan Matematika, 4(2), 657-672. https://doi.org/10.31004/cendekia.v4i2.263

Setiawan, E. P. (2020). PYTHAGORAS : Jurnal Pendidikan Matematika , 14 ( 2 ), 2019 , 163-177 Analisis muatan literasi statistika dalam buku teks matematika Kurikulum 2013. PYTHAGORAS: Jurnal Pendidikan Matematika, d(2), 163-177. https://doi.org/https://doi.org/10.21831/pg.v14i2.28558

Sharma, S. (2017). Definitions and models of statistical literacy : a literature review. Open Review of Educational Research, 4(1), 118-133. https://doi.org/10.1080/23265507.2017.1354313

Stoltz, P. G. (2003). Adversity Quotient (Mengubah Hambatan Menjadi Peluang) terjemahan. Jakarta: Gramedia.

Watson, J. M. (2004). Is statistical literacy relevant for middle school students? Towards Excellence in Mathematics, 1989, 3-10. https://doi.org/10.1.1.144.7227\&rep=rep1\&type=pdf

Watson, J. M., \& Callingham, R. a. (2003). Statistical Literacy: From Idiosyncratic to Critical Thinking Continued on Next Page. Curricular Development in Statistics Education, 2002, 116-162.

Wildani, J., Triyana, I. W., \& Mahmudah, W. (2019). LITERASI STATISTIS SISWA KELAS VIII THE STATISTICAL LITERACY OF 8 TH GRADE STUDENTS OF SMP. Vygotstky:Jurnal Pendidikan Matematika Dan Matematika, 1(2), 99-110. https://doi.org/https://doi.org/10.30736/vj.v1i2.137

Yolcu, A. (2014). Middle school students' statistical literacy: Role of grade level and gender. Statistics Education Research Journal, 13(2), 118-131. https://doi.org/https://eric.ed.gov/?id=EJ1047563 